\title{
Gaston Miron, Poèmes épars
}

\section{Lucie Picard}

\section{OpenEdition}

\section{Journals}

Édition électronique

URL : https://journals.openedition.org/studifrancesi/39892

DOI : $10.4000 /$ studifrancesi.39892

ISSN : 2427-5856

Éditeur

Rosenberg \& Sellier

\section{Édition imprimée}

Date de publication : 1 décembre 2004

Pagination : 421

ISSN : 0039-2944

\section{Référence électronique}

Lucie Picard, "Gaston Miron, Poèmes épars », Studi Francesi [En ligne], 143 (XLVIII | II) | 2004, mis en ligne le 30 novembre 2015, consulté le 19 mai 2021. URL : http://journals.openedition.org/ studifrancesi/39892 ; DOI : https://doi.org/10.4000/studifrancesi.39892

Ce document a été généré automatiquement le 19 mai 2021.

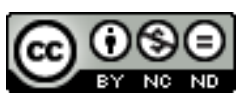

Studi Francesi è distribuita con Licenza Creative Commons Attribuzione - Non commerciale - Non opere derivate 4.0 Internazionale. 


\title{
Gaston Miron, Poèmes épars
}

\author{
Lucie Picard
}

\section{RÉFÉRENCE}

GASTON MIRON, Poèmes épars, édition préparée par Marie-Andrée Beaudet et Pierre Nepveu, Montréal, Éditions de l'Hexagone, 2003.

1 Explorer les «marges de L'homme rapaillé», œuvre-phare de la littérature québécoise comme de la poésie en langue française, voilà ce à quoi nous convient Marie-Andrée Beaudet et Pierre Nepveu, qui signent la préparation de la présente édition de Poèmes épars. L'ouvrage rassemble les poèmes, la plupart publiés précédemment en revue ou dans des anthologies, qui n'ont pas été intégrés à la «somme» mironienne que constitue L'homme rapaillé. Doté d'un riche appareil critique (qui comporte une section détaillée de notes ainsi qu'une présentation de Pierre Nepveu, qui situe ces «poèmes épars» dans l'économie générale de l'œuvre de Miron), ce recueil représente avant tout, comme le rappelle Nepveu, une occasion d'entendre la voix du poète, de découvrir certaines de ses nuances: une occasion de plaisir et de connaissance. 